\title{
Impact of Body Mass Index on Prognostically Relevant Breast Cancer Tumor Characteristics
}

\author{
Monika Eichholzer ${ }^{\mathrm{a}}$ Dorothy J. Huang ${ }^{\mathrm{b}, \mathrm{c}} \quad$ Alexandra Modlasiak ${ }^{\mathrm{b}, \mathrm{c}}$ \\ Seraina M. Schmid ${ }^{d}$ Andreas Schötzau ${ }^{\mathrm{e}}$ Sabine Rohrmann ${ }^{\mathrm{a}} \quad$ Uwe Güth $^{\mathrm{b}, \mathrm{c}, \mathrm{f}}$ \\ aDivision of Cancer Epidemiology and Prevention, Institute of Social and Preventive Medicine, University of Zurich, \\ bepartment of Obstetrics and Gynecology, 'Breast Center, University Hospital Basel, \\ ${ }^{\mathrm{d} D e p a r t m e n t}$ of Gynecology and Obstetrics, Breast center, Hospital Grabs, \\ 'Schötzau and Simmen Institute for Biomathematics, Basel, \\ fDepartment of Gynecology and Obstetrics, Breast center, Cantonal Hospital Winterthur, Switzerland
}

\section{Keywords}

Breast cancer - Body mass index - Tumor size .

Prognostic factors . Tumor detection

\section{Summary}

Background: This study analyzes the association of body mass index (BMI) and prognostically relevant breast cancer (BC) characteristics in a country that has been rather spared of the global obesity epidemic. Patients and Methods: Based on 20-year data (1999-2009, $\mathrm{n}=1,414)$ of the prospective relational $\mathrm{BC}$ database of the University Hospital Basel, Switzerland, the associations between BMI, tumor size and stage, histological subtype, grading, hormonal receptor status, HER2 status and 'triple-negative' status were evaluated. Multivariate analysis considered BMI and patient's age. Results: The association between increasing $\mathrm{BMI}$ and the above-mentioned variables were as follows (results described in each case: Beta-coefficient or odds ratio, $95 \%$ confidence interval, $p$ value): tumor size, (1) entire cohort: $0.03(0.01-0.05), p<0.001,(2)$ tumor found by selfpalpation: $0.05(0.03-0.07), p<0.001,(3)$ tumor found by radiological examination: $0.03(0-0.07), p=0.044$; advanced TNM stage: $1.16(1.02-1.31), p=0.022$; histological subtype: 1.04 (0.89-1.22), $\mathrm{p}=0.602$; unfavorable grading: 1.11 (1.00$1.25), \mathrm{p}=0.057$; positive estrogen receptor status: 0.95 (0.83-1.09), $\mathrm{p}=0.459$; positive HER2 status: 0.92 (0.74-1.15), $\mathrm{p}=0.467$; presence of a 'triple-negative' carcinoma: 1.19 (0.93-1.52), $p=0.165$. Consideration of only postmenopausal BC patients $(n=1,063)$ did attenuate the results, but did not change the direction of the associations with BMI. Conclusion: BMI was positively associated with TNM stage, grading and tumor size for tumors that were found by selfdetection, as well as for those lesions detected by radiological breast examinations.
Schlüsselwörter

Mammakarzinom · Body-Mass-Index · Tumorgröße · Prognosefaktoren - Tumordetektion

\section{Zusammenfassung}

Hintergrund: Die Studie analysiert, inwieweit der Body-MassIndex (BMI) Einfluss auf prognostisch relevante klinische und pathologische Mammakarzinom-Merkmale in einem Land hat, in dem die global zu beobachtende "obesity epidemic" bisher ausgeblieben ist. Patienten und Methoden: Aus den Daten der Mammakarzinom-Datenbank der Basler Universitäts-Frauenklinik, welche einen 20-Jahres-Zeitraum dokumentiert (1990-2009, 1459 Patientinnen), wurde der Einfluss des BMI auf folgende prognostisch relevante Variablen untersucht: Tumorgröße und -stadium, histologischer Subtyp, Grading, Hormonrezeptorstatus, HER2-Status, "triple-negativer»-Status. Das multivariate Berechnungsmodell berücksichtigte neben dem BMI das Alter der Patientin. Ergebnisse: Die Korrelationen zwischen steigendem BMI und den oben genannten Faktoren waren wie folgt (Angaben jeweils: Odds ratio (OR), 95\% Konfidenzintervall, p-Wert): Tumorgröße, a) alle Patientinnen: 0,03 $(0,01-0,05), p<0,001$, b) Tumor von Patientin selbst bemerkt/getastet: $0,05(0,03-$ $0,07), p<0,001, c)$ Tumor durch bildgebende Verfahren entdeckt: 0,03 (0-0,07), $p=0,044$; höheres TNM-Stadium: 1,16 $(1,02-1,31), p=0,022$; histologischer Subtyp: 1,04 (0,89-1,22), $p=0,602$; ungünstiges Grading: $1,11(1,00-1,25), p=0,057$; positiver Östrogenrezeptorstatus: 0,95 $(0,83-1,09), p=0,459$; positiver HER2-Status: 0,92 (0,74-1,15), $p=0,467$; Vorliegen eines "triple-negativen" Karzinoms: 1,19 (0,93-1,52), $p=$ 0,165 . Nur postmenopausale Patientinnen berücksichtigend ( $n=1063$ ), änderten sich die Ergebnisse nur marginal. Schlussfolgerungen: Mit steigendem BMI wurde eine positive Korrelation zu einem höheren TNM-Stadium, einem ungünstigen Grading und der Tumorgröße (sowohl für die Fälle, bei denen der Tumor von den Patientinnen selbst bemerkt/getastet wurde, als auch für die Tumoren, die mit radiologischen Verfahren detektiert wurden) gefunden.

\section{KARGER}

Fax +497614520714

Information@Karger.com

www.karger.com (c) 2013 S. Karger GmbH, Freiburg

661-3791/13/0083-0192\$38.00/0

Accessible online at:

www.karger.com/brc
Prof. Dr. med. Uwe Güth

Department of Gynecology and Obstetrics, Breast center,

Cantonal Hospital Winterthur

Brauerstrasse 15, 8401 Winterthur, Switzerland

uwe.gueth@unibas.ch 


\section{Introduction}

In most epidemiological studies, obesity is associated with an increased risk of postmenopausal breast cancer (BC), while an inverse relationship is observed in premenopausal women. In addition, being obese has been shown to influence BC prognosis adversely [1-3]. It has been suggested that larger tumor size, more advanced stage and grade of the tumor at diagnosis [4] could explain in part this bad outcome. The findings of several studies are in accordance with this hypothesis [5, 6]; however, others are not [7].

Unfavorable tumor characteristics may also explain the worse outcome of obese BC patients [2]. Furthermore, histological BC subtypes may differ in their associations with established BC risk factors [8-11]. The few studies exploring the association between body size and aggressive triple-negative BC (TNBC) reported largely inconsistent results [12]. On the other hand, evidence of a positive association between body size and estrogen receptor (ER)-positive $\mathrm{BC}$ is quite consistent [13-15]. For example, Phipps et al. [12] in their cohort study including 155,723 women enrolled in the Women's Health Initiative found an increased risk of TNBC (odds ratio $(\mathrm{OR})=1.35 ; 95 \%$ confidence interval $(\mathrm{CI})$ : 0.92-1.99) and ER-positive carcinomas (OR = 1.39; 95\% CI: 1.22-1.58) for women in the highest, compared with the lowest, body mass index (BMI) quartile. Even though the ERpositive BC subtype has a rather good prognosis, obesity in postmenopausal women may result in more biologically aggressive ER-positive tumors [16, 17].

To evaluate some of these controversial issues, we used data from a Swiss prospective BC database. Data from Switzerland is particularly interesting since the prevalence of overweight and obesity are low when compared to international statistics, and it seems, so far, that Switzerland, similar to a few other countries such as Italy or Sweden, has been spared from the globally observed 'obesity epidemic' [18-20]. For the present analysis, we evaluated the impact of BMI and age on the following prognostically relevant factors: tumor size (tumor detected by self-palpation or by radiological examination) and stage, histological subtype, grading, hormonal receptor status, HER2 status, 'triple-negative' status (hormonal receptor and HER2 status negative) and the risk score defined at the St. Gallen Expert Consensus Meeting in 2007 [21].

\section{Patients and Methods}

Based on the prospective relational web-based Basel Breast Cancer Database (BBCD) of the University Women's Hospital Basel (Basel, Switzerland), which documents all newly diagnosed and treated invasive breast carcinomas at this institution over a 20-year period (1990-2009, 1,459 patients), we evaluated the impact of BMI on prognostically relevant tumor characteristics of BC patients.

The predictor variable of our study was BMI. This variable was calculated using the following standard formula: body weight $(\mathrm{kg}) / \mathrm{height}\left(\mathrm{m}^{2}\right)$.
In this study, we exclusively used directly measured BMI data taken at the time of initial BC diagnosis. No BMI information was available for only 44 women of the entire BBCD cohort; thus, our study cohort comprised 1,415 patients. Besides age at initial diagnosis, the following clinicopathological features/characteristics were evaluated: tumor categories and stage according to the current American Joint Committee on Cancer (AJCC)/International Union Against Cancer (UICC) TNM classification [22, 23]; histological subtype; grading; hormonal receptor status (ER status and progesterone receptor (PR) status); HER2 status (HER2 has routinely been assessed for all patients since $2002(\mathrm{n}=665)$ and was available for 660 patients ( $46.6 \%$ of the entire study cohort)); TNBC; and risk score (as defined at the St. Gallen Expert Consensus Meeting in 2007) [21].

In addition, we considered the method of tumor detection, and evaluated 3 different methods: self-detection, clinical breast examination and radiological breast examination including mammography and sonography.

Table 1. Basel Breast Cancer Database 1990-2009: clinicopathological characteristics of 1415 patients

\begin{tabular}{|c|c|}
\hline \multicolumn{2}{|l|}{ Characteristic } \\
\hline Age at diagnosis, median in years (range) & $61(26-95)$ \\
\hline BMI median (range) & $24.7(14.3-53.3)$ \\
\hline$<18.5, \mathrm{n}(\%)$ & $38(2.7)$ \\
\hline $18.5-24.9, \mathrm{n}(\%)$ & $712(50.3)$ \\
\hline $25-29.9, \mathrm{n}(\%)$ & $425(30.0)$ \\
\hline$\geq 30, \mathrm{n}(\%)$ & $240(17.0)$ \\
\hline Tumor size, median in mm (range) & $20(0-220)$ \\
\hline $\mathrm{T} 1, \mathrm{n}(\%)$ & $717(50.7)$ \\
\hline $\mathrm{T} 2, \mathrm{n}(\%)$ & $523(37.0)$ \\
\hline $\mathrm{T} 3, \mathrm{n}(\%)$ & $80(5.7)$ \\
\hline Non-inflammatory T4, n (\%) & $70(5.0)$ \\
\hline Inflammatory carcinoma & $23(1.6)$ \\
\hline \multicolumn{2}{|l|}{ (no tumor size recorded), n (\%) } \\
\hline Missing, $\mathrm{n}$ & 2 \\
\hline \multicolumn{2}{|l|}{ TNM stage, $\mathrm{n}(\%)$} \\
\hline I & $527(37.2)$ \\
\hline II & $558(39.5)$ \\
\hline III & $249(17.6)$ \\
\hline IV & $81(5.7)$ \\
\hline \multicolumn{2}{|l|}{ Histological subtype, n (\%) } \\
\hline Ductal invasive & $1097(78.4)$ \\
\hline Lobular invasive & $197(14.1)$ \\
\hline Other types & $106(7.5)$ \\
\hline Missing, $\mathrm{n}$ & 15 \\
\hline \multicolumn{2}{|l|}{ Grading, n (\%) } \\
\hline $\mathrm{G} 1 / \mathrm{G} 2$ & $786(57.6)$ \\
\hline G3 & $578(42.4)$ \\
\hline Missing, $\mathrm{n}$ & 51 \\
\hline \multicolumn{2}{|l|}{ Hormone receptor status, $\mathrm{n}(\%)$} \\
\hline ER positive /PR positive & $867(64.1)$ \\
\hline ER negative / PR negative & $239(17.7)$ \\
\hline Missing (n) & 63 \\
\hline \multicolumn{2}{|l|}{ HER2 receptor status (2002-2009) } \\
\hline Known, $\mathrm{n}$ & 660 \\
\hline Positive, n (\%) & $113(17.1)$ \\
\hline \multicolumn{2}{|l|}{ 'Triple negativity' (2002-2009) } \\
\hline ER/PR/HER2 known, n & 660 \\
\hline Positive, $\mathrm{n}(\%)$ & $70(10.6)$ \\
\hline \multicolumn{2}{|l|}{ St. Gallen risk score (2002-2009) } \\
\hline Known ER/PR/HER2 status ${ }^{\mathrm{a}}$, n & 579 \\
\hline Low, n $(\%)$ & $82(14.2)$ \\
\hline Intermediate, n (\%) & $400(69.1)$ \\
\hline High, n (\%) & $97(16.7)$ \\
\hline \multicolumn{2}{|c|}{$\begin{array}{l}\mathrm{BMI}=\text { body mass index, } \mathrm{ER}=\text { estrogen receptor, } \\
\mathrm{PR}=\text { progesterone receptor. } \\
\text { a Only applicable for patients who had primary surgery } \\
\text { (i.e. pTNM classification). }\end{array}$} \\
\hline
\end{tabular}


Statistical Analysis

To evaluate the impact of BMI and age on tumor characteristics (tumor size and stage, histological subtype, grading, hormonal receptor status, HER2 status, 'triple-negative' status and the St. Gallen risk score) we created multivariate models (linear or logistic regression) including BMI and patient's age at diagnosis for $(1)$ the entire cohort $(n=1,415)$, and $(2)$ for postmenopausal women only $(n=1,063)$. Results of linear regression models are reported as beta-coefficients and corresponding 95\% CIs; results of logistic regression models are reported as ORs with corresponding 95\% CIs. Statistical analyses were performed with R Development Core Team software, version 2.5.0 (Vienna, Austria).

Data collection methods and study design were approved by the Institutional Ethical Review Board.

\section{Results}

Of the 1,415 BC patients included in the present study, 50.3\% had normal body weight (BMI $18.5-<25 \mathrm{~kg} / \mathrm{m}^{2}$ ), $30.0 \%$ were overweight (BMI $25-<30 \mathrm{~kg} / \mathrm{m}^{2}$ ) and $17.0 \%$ obese (BMI $\geq 30 \mathrm{~kg} / \mathrm{m}^{2}$ ); the median age was 61 years (range: $26-95$ ). Clin- icopathological features of this cohort of patients are summarized in table 1 .

Table 2 shows the associations between tumor characteristics, BMI and age. The multivariate analyses included the directly measured BMI (as a continuous variable) and patient's age, each at the time of the initial cancer diagnosis.

With regard to the impact of age on tumor characteristics, the present study revealed a positive association between advancing age and the probability of being diagnosed with lobular instead of ductal BC $(\mathrm{OR}=1.18 ; 95 \% \mathrm{CI}=1.06-1.32$, $\mathrm{p}=0.003)$. Furthermore, increasing age was associated with a more favorable grading $(\mathrm{OR}=0.91 ; 95 \% \mathrm{CI}=0.84-0.98$, $\mathrm{p}=0.019)$ and a higher probability of a positive ER status $(\mathrm{OR}=1.23 ; 95 \% \mathrm{CI}=1.11-1.35, \mathrm{p}<0.001)$. With increasing age, $\mathrm{TNBC}$ were diagnosed less often $(\mathrm{OR}=0.71 ; 95 \% \mathrm{CI}=$ $0.59-0.86)$. No associations were observed between advancing age and tumor size (independent of detection modus), TNM and HER2 status, and St. Gallen risk score.

Table 2. Association of BMI and age with prognostic relevant breast cancer characteristics

\begin{tabular}{|c|c|c|c|c|}
\hline & Entire cohort & $\mathrm{p}$ value ${ }^{\mathrm{a}}$ & Postmenopausal women & p value ${ }^{a}$ \\
\hline \multicolumn{5}{|l|}{ Beta-coefficient (95\% CI) } \\
\hline \multicolumn{5}{|l|}{ Tumor size (all patients) } \\
\hline $\mathrm{BMI}^{\mathrm{b}}$ & $0.03(0.01-0.05)$ & $<0.001$ & $0.03(0.01-0.05)$ & 0.002 \\
\hline $\operatorname{Age}^{\mathrm{c}}$ & $0.01(0-0.02)$ & 0.082 & $0.01(0.02-0.05)$ & $<0.001$ \\
\hline \multicolumn{5}{|c|}{ Tumor size (tumor detected by self-examination) } \\
\hline $\mathrm{BMI}^{\mathrm{b}}$ & $0.05(0.03-0.07)$ & $<0.001$ & $0.04(0.02-0.06)$ & $<0.001$ \\
\hline $\operatorname{Age}^{\mathrm{c}}$ & $0.001(0-0.02)$ & 0.188 & $0.01(-0.01-0.03)$ & 0.349 \\
\hline \multicolumn{5}{|c|}{ Tumor size (tumor detected by mammography or sonography) } \\
\hline $\mathrm{BMI}^{\mathrm{b}}$ & $0.03(0-0.07)$ & 0.044 & $0.03(0.0-0.07)$ & 0.076 \\
\hline $\mathrm{Age}^{\mathrm{c}}$ & $0(-0.03-0.03)$ & 0.840 & $0.02(-0.03-0.06)$ & 0.457 \\
\hline \multicolumn{5}{|l|}{ OR $(95 \%$ CI $)$} \\
\hline \multicolumn{5}{|l|}{ TNM stage (III/IV vs. I/II) } \\
\hline $\mathrm{BMI}^{\mathrm{b}}$ & $1.16(1.02-1.31)$ & 0.022 & $1.06(0.92-1.23)$ & 0.402 \\
\hline $\mathrm{Age}^{\mathrm{c}}$ & $0.97(0.89-1.06$ & 0.525 & $1.01(0.88-1.17)$ & 0.833 \\
\hline \multicolumn{5}{|c|}{ Histological subtype (lobular vs. ductal) } \\
\hline $\mathrm{BMI}^{\mathrm{b}}$ & $1.04(0.89-1.22)$ & 0.602 & $1.05(0.89-1.25)$ & 0.573 \\
\hline $\mathrm{Age}^{\mathrm{c}}$ & $1.18(1.06-1.32)$ & 0.003 & $1.09(0.92-1.28)$ & 0.324 \\
\hline \multicolumn{5}{|l|}{ Grading (3 vs. 1 and 2 ) } \\
\hline $\mathrm{BMI}^{\mathrm{b}}$ & $1.11(1.00-1.25)$ & 0.057 & $1.10(0.97-1.2)$ & 0.135 \\
\hline $\operatorname{Age}^{\mathrm{c}}$ & $0.91(0.84-0.98)$ & 0.019 & $0.91(0.81-1.03)$ & 0.151 \\
\hline \multicolumn{5}{|l|}{ ER status (positive vs. negative) } \\
\hline $\mathrm{BMI}^{\mathrm{b}}$ & $0.95(0.83-1.09)$ & 0.459 & $0.99(0.84-1.16)$ & 0.874 \\
\hline $\operatorname{Age}^{c}$ & $1.23(1.11-1.35)$ & $<0.001$ & $1.20(1.02-1.40)$ & 0.025 \\
\hline \multicolumn{5}{|l|}{ HER2 status } \\
\hline (2002-2009: positive vs. negative) & & & $0.92(0.72-1.18)$ & 0.526 \\
\hline $\mathrm{BMI}^{\mathrm{b}}$ & $\begin{array}{l}0.92(0.74-1.15) \\
0.95(082-1.10)\end{array}$ & $\begin{array}{l}0.467 \\
0.495\end{array}$ & $0.97(0.77-1.22)$ & 0.786 \\
\hline $\mathrm{Age}^{\mathrm{c}}$ & $0.95(0.82-1.10)$ & 0.495 & & \\
\hline \multicolumn{5}{|c|}{ 'Triple negativity' (2002-2009: yes vs. no) } \\
\hline $\mathrm{BMI}^{\mathrm{b}}$ & $1.19(0.93-1.52)$ & 0.165 & $0.87(0.64-1.17)$ & 0.350 \\
\hline $\mathrm{Age}^{\mathrm{c}}$ & $0.71(0.59-0.86)$ & $<0.001$ & $1.35(0.99-1.84)$ & 0.052 \\
\hline \multicolumn{5}{|c|}{ St. Gallen risk score (2002-2009: high vs. low) } \\
\hline $\mathrm{BMI}^{\mathrm{b}}$ & $1.24(1.00-1.55)$ & 0.049 & $1.20(0.94-1.53)$ & 0.154 \\
\hline $\mathrm{Age}^{\mathrm{c}}$ & $0.88(0.75-1.02)$ & 0.091 & $0.89(0.70-1.12)$ & 0.308 \\
\hline
\end{tabular}


Regarding the impact of BMI on tumor characteristics, increasing BMI was associated with increasing tumor size in the entire cohort, such that the tumor increased by $3 \mathrm{~mm}$ per 5 unit change in BMI (beta-coefficient 0.03 ; $95 \% \mathrm{CI}=0.01$ $0.05, \mathrm{p}<0.001)$ and in patients who found the tumor by selfpalpation (beta-coefficient $=0.05 ; 95 \%$ CI $=0.03-0.07$, $\mathrm{p}<0.001)$ as well as in women in whom the cancer was detected by radiological examination (mammography or sonography) (beta-coefficient $=0.03 ; 95 \% \mathrm{CI}=0-0.07, \mathrm{p}=0.044$ ).

Increasing BMI was also related to more advanced TNM stage at diagnosis $(\mathrm{OR}=1.16 ; 95 \% \mathrm{CI}=1.02-1.31, \mathrm{p}=0.022)$, unfavorable grading $(\mathrm{OR}=1.11 ; 95 \% \mathrm{CI}=1.00-1.25, \mathrm{p}=$ $0.057)$ and a higher St. Gallen risk score (OR $=1.24$; $95 \% \mathrm{CI}$ $=1.00-1.55, \mathrm{p}=0.049)$. No significant associations were observed between BMI and histological subtype (lobular vs. ductal), positive ER status, positive HER2 status, and the presence of a TNBC.

Limiting the group of women to postmenopausal BC patients attenuated the results mentioned above, but did not change the direction of the correlations/associations (see table 2) with the exception of triple negativity and age.

\section{Discussion}

There is increasing evidence that BMI is inversely associated with $\mathrm{BC}$ prognosis $[1,7,17]$. However, at present, the causal mechanisms are still under investigation. This may partly be due to a poor compliance to BC screening. Compliance and persistence with medical measures are strongly determined by personal motivations, which are determined by a considerable number of individual psychosocial and medical factors. Few published studies have evaluated the impact of body weight on compliance and persistence with BC therapy [2, 24-26]. However, the complex relationship between BMI and acceptance of medical measures has been rather well examined with regards to mammography screening rates. Some authors reported significantly lower compliance with BC screening in obese women [27-29], although others did not confirm this finding in a large population-based analysis of more than 130,000 women [30]. The reasons why a significant number of obese patients delay or refuse to participate in cancer screening programs are not yet fully understood. One of the most common reasons women give is the embarrassment of being weighed or having to undergo a physical exam with even more embarrassing aspects to endure (e.g. too small gowns, examination tables, instruments) [28, 29, 31]. A further crucial point is the physician's attitude towards obese patients. The literature reports a considerable amount of negative and stereotypical attitudes toward obese patients that can be interpreted as decreased respect for obese patients [29, 32, 33]. This attitude is clearly felt by the patients, influencing them in their behavior and decisions [32-34]. Efforts are needed to avoid these deterrents.
The worse outcome in obese women could also be due to more advanced stage at diagnosis and/or the difficulty in palpating these tumors. Additionally, obese BC patients may have more aggressive cancers [17]. Obesity is accompanied with the up-regulation of various cellular proliferation pathways [35]. Adipokines and estrogens, produced in adipose tissue, may enhance tumor cell proliferation and metastasis [35-37], and may potentially result in more aggressive ERpositive cancers in postmenopausal women [16].

In the present study, BMI was significantly associated with tumor size. This applied not only to the cases in which the tumor was found by self-detection, but also to lesions detected by radiological breast examinations. In addition, a higher BMI was positively correlated with advanced TNM stage, unfavorable grading, and a higher St. Gallen risk score. No associations were observed between BMI and histological subtype, ER status, HER2 status and TNBC. Higher age, on the other hand, increased the probability of lobular instead of ductal BC, less TNBC, ER positivity and more favorable grading. In the subgroup of postmenopausal women, the above-mentioned findings were attenuated but did not change the direction of the associations.

\section{Age and Prognostically Relevant Tumor Characteristics}

$\mathrm{BC}$ in elderly women seems to be of a less aggressive nature than in younger patients [38]. Our observed associations with age are in accordance with the findings in the literature for Caucasian women [39]. At a higher age, tumors are more often ER positive [39-42]. In the study by Parise et al. [39], the increase in the percentage of the $\mathrm{ER}^{+} / \mathrm{PR}^{+} / \mathrm{HER}^{-}$subtype with increasing age almost mirrored the increasing proportion of BC cases in white women [39]. This BC subtype has the best overall 5-year relative cumulative survival [40]. On the other hand, the triple negative subtypes are found more often in younger than in older women [39, 40, 43-45].

\section{BMI and Breast Cancer: Tumor Size, TNM stage, Grading, and St. Gallen Risk Score}

Although in several reports obesity was positively associated with advanced stage, increased tumor size and unfavorable grading of breast carcinomas at diagnosis, these findings were not confirmed in other surveys [7]. Accordingly, Wasserman et al. [46] observed no association between BMI and disease stage at diagnosis in 301 postmenopausal women of the Women's Healthy Eating and Living study. The same was true for women of any age in another study [47]. Similarly, in the study by Chagpar et al. [7], no association was observed between BMI and tumor size, lymph node status, or disease stage at diagnosis in mostly postmenopausal women with hormonally sensitive BC. In contrast, several other studies observed a positive association between BMI and disease stage, tumor size and lymph node status at diagnosis [5, 6, 48], as we did in our survey for tumor size and stage. In a study carried out in the canton of Geneva, Switzerland [2], invasive 
carcinomas larger than $1 \mathrm{~cm}$ were more frequently impalpable in obese women $(22 \%)$ than in normal/underweight women $(12 \%)$. It may be more difficult for clinicians and women to palpate a tumor in a large breast than in a small one. Thus, obese women with larger breasts may have larger tumors and more advanced tumor stages at diagnosis than lean women with small breasts. Accordingly, in a study of 2,863 patients diagnosed with $\mathrm{BC}$ in Wisconsin, elevated BMI was associated with a greater probability of nonlocalized tumors in selfdetected cancers, but in women whose tumors were found by screening mammography or by clinical breast examination, BMI was not related to disease stage [49]. In the present study, however, BMI was found to be a significant factor for tumors found by self-detection, as well as for those detected by radiological breast examinations. Thus, either both methods for tumor detection are impaired by large breasts, or larger tumors in larger breasts could be the consequence of obesity. In this context, the results of an Australian study [50] on the outcome of mammography in women with large breasts is of interest: the sensitivity and specificity of mammography were greater in women with larger breasts than in other women.

Non-adherence to BC screening is another possible explanation for our findings. Obese women are less likely to follow physician's recommendations for breast and cervical cancer screening [29]. On the basis of 10 studies, among women in the U.S., Cohen et al. found that obesity most likely is a barrier to screening for $\mathrm{BC}$, particularly among white women [51], although this is not universally so [52]. In the present study, we could not comment on this explanation because until now only opportunistic screening exists in the Basel region.

\section{BMI and Breast Cancer: ER status, HER2 status and TNBC} Obesity may affect $\mathrm{BC}$ risk by increasing circulating endogenous estrogen levels [53]. Thus, the association between body weight and BC risk may be modified by the tumor's ER and PR status. The summarized findings of 9 cohort and 22 casecontrol studies comparing the highest versus the reference categories of relative body weight observed that the risk for $\mathrm{ER}^{+} \mathrm{PR}^{+}$tumors was $20 \%$ lower $(95 \% \mathrm{CI}=-30$ to $-8 \%)$ among premenopausal and $82 \%$ higher (95\% CI $=55-114 \%)$ among postmenopausal women [15]. No associations were observed for $\mathrm{ER}^{-} \mathrm{PR}^{-}$or $\mathrm{ER}^{+} \mathrm{PR}^{-}$tumors. More recent studies confirmed these findings $[2,12,54,55]$. The association between $\mathrm{BMI}$ and BC risk is thus dependent on the tumor's ER/PR status and the woman's menopausal status, and in some studies the risk was modified by hormone replacement therapy (HRT) $[42,55,56]$.

In addition, HER2 status may be inversely associated with BMI, independent of ER status [57], as shown in a study of postmenopausal women. Phipps et al. [58], on the other hand, found no difference in the association between BMI and HER2 status. Additional studies with sufficient numbers of
HER2-positive and HER2-negative tumors are needed to clarify the association between HER2 status and BMI.

Data examining obesity as a risk factor for TNBC are limited and inconsistent $[59,60]$. Case-control studies that evaluated BMI in women irrespective of menopausal status and in postmenopausal women found no association with TNBC [58, 60-62]. Pooling 2 case-control studies revealed a positive association between BMI and $\mathrm{TNBC}(\mathrm{OR}=2.7 ; 95 \% \mathrm{CI}=$ 1.0-7.5) in postmenopausal women not using HRT [58]. No association was observed in HRT users. In a prospective study, for postmenopausal women in the highest versus the lowest BMI quartile, Phipps et al. [12] observed a 1.35-fold $(95 \%$ CI $=0.92-1.99)$ non-significantly increased risk of TNBC without association with HRT use.

\section{Strength and Limitations}

One of the strengths of our study is the comprehensive data set prospectively collected from a university breast center covering a recent study period (1997-2009). Furthermore, for our predictor variable 'BMI' we only used directly measured BMI data. These are much more reliable than self-reported BMI data [63]. Individuals tend to underestimate their weight and overestimate their height. BMI was relatively stable over the entire study period. It is a distinct finding in the Swiss general population that overweight and obesity rates have remained comparatively stable over the last 12 years [18]. Furthermore, we demonstrated that this BMI trend in the general population was similar to that in a cohort of BC patients [64].

However, the limitations of our study must also be considered. The numbers of triple-negative and HER2-positive cases were small, reflecting the rarity of these tumor types, and this limits the possibilities of drawing meaningful conclusions about the association of BC with BMI for these cases. Moreover, HRT use and screening for BC could not be taken into account in the present analysis due to lack of adequate data in these areas.

\section{Conclusion}

In the present study, BMI was a significant factor for tumor size at diagnosis; this applied not only to the cases in which the tumor was found by self-detection, but also to lesions detected by radiological breast examinations. Even though these results strengthen the evidence for a causal relationship between BMI and $\mathrm{BC}$ outcome, we cannot exclude nonadherence to screening for $\mathrm{BC}$ as a possible explanation for our findings.

\section{Disclosure Statement}

The authors declare that there are no financial or personal relationships with other people or organizations that could inappropriately influence the work reported or the conclusions, implications, or opinions stated. 


\section{Funding Source}

This study was supported by the 'Krebsliga beider Basel', grant 09-2009.

The study sponsor had no influence whatsoever on the reported data.

\section{References}

1 Carmichael AR: Obesity as a risk factor for development and poor prognosis of breast cancer. BJOG 2006;113:1160-1166

2 Deglise C, Bouchardy C, Burri M, et al.: Impact of obesity on diagnosis and treatment of breast cancer. Breast Cancer Res Treat 2010;120:185-193.

3 World Cancer Research Fund/American Institute for Cancer Research: Food, Nutrition, Physical Activity, and the Prevention of Cancer: A Global Perspective. Washington DC: AICR, 2007.

4 Majed B, Moreau T, Senouci K, et al.: Is obesity an independent prognosis factor in woman breast cancer? Breast Cancer Res Treat 2008;111:329-342.

5 Moorman PG, Jones BA, Millikan RC, et al.: Race, anthropometric factors, and stage at diagnosis of breast cancer. Am J Epidemiol 2001;153:284-291

6 Loi S, Milne RL, Friedlander ML, et al.: Obesity and outcomes in premenopausal and postmenopausal breast cancer. Cancer Epidemiol Biomarkers Prev 2005;14:1686-1691.

7 Chagpar AB, McMasters KM, Saul J, et al.: Body mass index influences palpability but not stage of breast cancer at diagnosis. Am Surg 2007;73:555560; discussion 560.

$>8$ Reeves GK, Pirie K, Green J, et al.: Reproductive factors and specific histological types of breas cancer: Prospective study and meta-analysis. Br J Cancer 2009;100:538-544.

9 Slanger TE, Chang-Claude JC, Obi N, et al.: Menopausal hormone therapy and risk of clinical breast cancer subtypes. Cancer Epidemiol Biomarkers Prev 2009:18:1188-1196.

10 Li CI, Daling JR, Malone KE, et al.: Relationship between established breast cancer risk factors and risk of seven different histologic types of invasive breast cancer. Cancer Epidemiol Biomarkers Prev 2006;15:946-954.

11 Phipps AI, Li CI, Kerlikowske K, et al.: Risk factors for ductal, lobular, and mixed ductal-lobular breast cancer in a screening population. Cancer Epidemiol Biomarkers Prev 2010;19:1643-1654.

12 Phipps AI, Chlebowski RT, Prentice R, et al.: Body size, physical activity, and risk of triple-negative and estrogen receptor-positive breast cancer. Cancer Epidemiol Biomarkers Prev 2011;20:454-463.

13 Enger SM, Ross RK, Paganini-Hill A, et al.: Body size, physical activity, and breast cancer hormone receptor status: Results from two case-contro studies. Cancer Epidemiol Biomarkers Prev 2000; 9:681-687.

14 Colditz GA, Rosner BA, Chen WY, et al.: Risk factors for breast cancer according to estrogen and progesterone receptor status. J Natl Cancer Inst 2004;96:218-228.

15 Suzuki R, Orsini N, Saji S, et al.: Body weight and incidence of breast cancer defined by estrogen and progesterone receptor status-a meta-analysis. Int J Cancer 2009;124:698-712.

16 Tchernof A, Despres JP: Sex steroid hormones, sex hormone-binding globulin, and obesity in men and women. Horm Metab Res 2000;32:526-536.

17 Protani M, Coory M, Martin JH: Effect of obesity on survival of women with breast cancer: Systematic review and meta-analysis. Breast Cancer Res Treat 2010;123:627-635.
18 Eichholzer M, Bovey F, Jordan P, et al.: Daten zum Übergewicht und zu Ernährungsgewohnheiten der Schweizerischen Gesundheitsbefragung 2007. Praxis (Bern 1994) 2010;99:17-25.

19 Faeh D, Bopp M: Proposed obesity body mass index correction for self-reported data may not be appropriate. J Epidemiol Community Health 2009;63:863-864

20 Doak CM, Wijnhoven TM, Schokker DF, et al.: Age standardization in mapping adult overweight and obesity trends in the WHO European Region. Obes Rev 2012;13:174-191.

21 Goldhirsch A, Wood WC, Gelber RD, et al.: Progress and promise: Highlights of the international expert consensus on the primary therapy of early breast cancer 2007. Ann Oncol 2007;18:11331144.

22 Edge S, Byrd D, Compton C, et al. (eds): AJCC Cancer Staging Manual, ed 7th. New York, Springer, 2009

23 Sobin L, Gospodarowicz M, Wittekind C (eds): UICC: TNM Classification of Malignant Tumors, ed 7th. Oxford, Wiley-Blackwell, 2009.

24 Buist DS, Ichikawa L, Prout MN, et al.: Receipt of appropriate primary breast cancer therapy and adjuvant therapy are not associated with obesity in older women with access to health care. J Clin Oncol 2007;25:3428-3436

25 Maskarinec G, Pagano I, Lurie G, et al.: Factors affecting survival among women with breast cancer in Hawaii. J Womens Health (Larchmt) 2011; 20:231-237.

26 Schmid SM, Eichholzer M, Bovey F, et al.: Impact of body mass index on compliance and persistence to adjuvant breast cancer therapy. Breast 2012; 21:487-492.

27 Wee CC, McCarthy EP, Davis RB, et al.: Screening for cervical and breast cancer: Is obesity an unrecognized barrier to preventive care? Ann Intern Med 2000;132:697-704

28 Fontaine KR, Heo M, Allison DB: Body weight and cancer screening among women. J Womens Health Gend Based Med 2001;10:463-470.

29 Ferrante JM, Chen PH, Crabtree BF, et al.: Cancer screening in women: Body mass index and adherence to physician recommendations. Am J Prev Med 2007;32:525-531.

30 Berz D, Sikov W, Colvin G, et al.: ,Weighing in“ on screening mammography. Breast Cancer Res Treat 2009;114:569-574.

31 Destounis S, Newell M, Pinsky R: Breast imaging and intervention in the overweight and obese patient. AJR Am J Roentgenol 2011;196:296-302.

32 Price JH, Desmond SM, Krol RA, et al.: Family practice physicians' beliefs, attitudes, and practices regarding obesity. Am J Prev Med 1987;3:339345

33 Puhl R, Brownell KD: Bias, discrimination, and obesity. Obes Res 2001;9:788-805.

34 Huizinga MM, Cooper LA, Bleich SN, et al.: Physician respect for patients with obesity. J Gen Intern Med 2009;24:1236-1239.

35 Calle EE, Kaaks R: Overweight, obesity and cancer: Epidemiological evidence and proposed mechanisms. Nat Rev Cancer 2004;4:579-591.
6 Daling JR, Malone KE, Doody DR, et al.: Relation of body mass index to tumor markers and surviva among young women with invasive ductal breast carcinoma. Cancer 2001;92:720-729.

37 Cowey S, Hardy RW: The metabolic syndrome: A high-risk state for cancer? Am J Pathol 2006;169: 1505-1522.

38 Cheung KL, Wong AW, Parker H, et al.: Pathological features of primary breast cancer in the elderly based on needle core biopsies-a large series from a single centre. Crit Rev Oncol Hematol 2008;67:263-267.

39 Parise CA, Bauer KR, Caggiano V: Variation in breast cancer subtypes with age and race/ethnicity. Crit Rev Oncol Hematol 2010;76:44-52.

40 Parise CA, Bauer KR, Brown MM, et al.: Breast cancer subtypes as defined by the estrogen receptor (ER), progesterone receptor (PR), and the human epidermal growth factor receptor 2 (HER2) among women with invasive breast cancer in California, 1999-2004. Breast J 2009;15:593-602.

41 Neven P, Van Calster B, Van den Bempt I, et al: Age interacts with the expression of steroid and HER-2 receptors in operable invasive breast cancer. Breast Cancer Res Treat 2008;110:153-159.

42 Ritte R, Lukanova A, Berrino F, et al.: Adiposity, hormone replacement therapy use and breast cancer risk by age and hormone receptor status: A large prospective cohort study. Breast Cancer Res;14:R76.

43 Bauer KR, Brown M, Cress RD, et al.: Descriptive analysis of estrogen receptor (ER)-negative, progesterone receptor (PR)-negative, and HER2negative invasive breast cancer, the so-called triplenegative phenotype: A population-based study from the California Cancer Registry. Cancer 2007; 109:1721-1728.

44 Carey LA, Perou CM, Livasy CA, et al.: Race, breast cancer subtypes, and survival in the Carolina Breast Cancer Study. JAMA 2006;295:2492-2502.

45 Lund MJ, Butler EN, Bumpers HL, et al.: High prevalence of triple-negative tumors in an urban cancer center. Cancer 2008;113:608-615.

46 Wasserman L, Flatt SW, Natarajan L, et al.: Correlates of obesity in postmenopausal women with breast cancer: Comparison of genetic, demographic, disease-related, life history and dietary factors. Int J Obes Relat Metab Disord 2004;28:49-56.

47 Kim YA, Lee CW: Effects of obesity on breast cancer stage at diagnosis in Korean women. Eur J Cancer Prev 2004:13:13-17.

48 Cui Y, Whiteman MK, Flaws JA, et al.: Body mass and stage of breast cancer at diagnosis. Int J Cancer 2002;98:279-283.

49 Reeves MJ, Newcomb PA, Remington PL, et al. Body mass and breast cancer. Relationship between method of detection and stage of disease. Cancer 1996;77:301-307.

50 Gayde C, Goolam I, Bangash HK, et al.: Outcome of mammography in women with large breasts. Breast 2012;21:493-498.

51 Cohen SS, Palmieri RT, Nyante SJ, et al.: Obesity and screening for breast, cervical, and colorectal cancer in women: A review. Cancer 2008;112:18921904 
52 Reidpath DD, Crawford D, Tilgner L, et al.: Relationship between body mass index and the use of healthcare services in australia. Obes Res 2002; 10:526-531.

53 Rose DP, Komninou D, Stephenson GD: Obesity, adipocytokines, and insulin resistance in breas cancer. Obes Rev 2004;5:153-165.

54 Setiawan VW, Monroe KR, Wilkens LR, et al. Breast cancer risk factors defined by estrogen and progesterone receptor status: The multiethnic cohort study. Am J Epidemiol 2009;169:12511259.

55 Canchola AJ, Anton-Culver H, Bernstein L, et al. Body size and the risk of postmenopausal breast cancer subtypes in the California Teachers Study cohort. Cancer Causes Control 2012[Epub ahead of print].
56 Suzuki R, Rylander-Rudqvist T, Ye W, et al.: Body weight and postmenopausal breast cancer risk defined by estrogen and progesterone receptor status among swedish women: A prospective cohort study. Int J Cancer 2006;119:1683-1689.

57 Van Mieghem T, Leunen K, Pochet N, et al. Body mass index and HER-2 overexpression in breast cancer patients over 50 years of age. Breast Cancer Res Treat 2007;106:127-133.

58 Phipps AI, Malone KE, Porter PL, et al.: Body size and risk of luminal, HER2-overexpressing, and triple-negative breast cancer in postmenopausal women. Cancer Epidemiol Biomarkers Prev 2008; 17:2078-2086.

59 Davis AA, Kaklamani VG: Metabolic syndrome and triple-negative breast cancer: A new paradigm. Int J Breast Cancer 2012;2012:809291.
60 Gierach GL, Burke A, Anderson WF: Epidemiology of triple negative breast cancers. Breast Dis 2010;32:5-24.

61 Millikan RC, Newman B, Tse CK, et al. Epidemiology of basal-like breast cancer. Breast Cancer Res Treat 2008;109:123-139.

62 Yang XR, Sherman ME, Rimm DL, et al.: Differences in risk factors for breast cancer molecular subtypes in a population-based study. Cancer Epidemiol Biomarkers Prev 2007;16:439-443.

63 Gorber SC, Tremblay M, Moher D, et al.: A comparison of direct vs. self-report measures for assessing height, weight and body mass index: A systematic review. Obes Rev 2007;8:307-326.

64 Eichholzer M, Schmid SM, Bovey F, et al.: Impact of overweight and obesity on postmenopausal breast cancer: Analysis of 20-year data from Switzerland. Arch Gynecol Obstet 2012;285:797-803. 